\title{
Etê Etê Morhà...
}

\author{
MARIA ELSA DA ROCHA
}

ona Laura é, ou julga ser, uma senhora bem da nossa sociedade. Muito pedante e com grande lata para exibicionismo, compõe com requintes de arte as pregas do seu sari Khatau. Virando-se e revirando-se à mesa de toilette de três grandes espelhos que refletem a sua figura ainda com laivos de frescura, olha de esguelha a filha, refastelada no divã e adverte-a mal humorada:

"Não te vais arranjar ainda? Já sabes, hoje vais passar a tarde com a avó e diz-Ihe que eu não te pude acompanhar porque tenho uma reunião de Mahila Mandal... Percebes?"

"Percebo, percebo que me mandas fazer o frete e vais para onde muito te apetece". E dizendo isto, a morena Fatiminha encolheu os ombros e, num gesto arrapazado, jogou o magazine para a mesinha de cabeceira que recebeu um choque de um abalo sísmico, derrubando os objetos aí colocados. Coçou com estilo a sua penteada grenha, segundo o modelo em voga para maiores de catorze anos, e plantou-se ao lado da mãe...

"Menina!", respondeu a mãe. "Onde arranjaste tão lindas maneiras e como te atreves a pensar que eu não vou a essa reunião?"

"Saibá! Eu não penso nada; só disse que me mandas fazer o frete! Acho que não há nada de mal em dizer isto... A avó já me disse que tu, quando tinhas a minha idade, ainda eras pior do que eu..."

"Pois fica sabendo que ela não me aturou nem metade do que eu te suporto, bruxa!"

Por resposta a jovem Fátima atirou um assobio de gaita de foles, seguido de um teatral Saibá que pôs os nervos da mãe em franja. 
Contudo, a mãe da Fátima achou bem passar por cima daquilo e virou às recomendações:

"Toma sentido nos assuntos de que falas com a avozinha! Estás feita uma Maria portuguesa e isto pode aborrecê-la muito! Tens de ser mais calma e-"

"Oh mãe, é o sermão de sempre, não?"

"Quem devia fazer o sermão eras tu, pois não? Deves refletir no que dizes!"

"Bem, Saibá, não te zangues!"

"Não estou a zangar-me!"

"Mas parece!"

"Não quero que faças má figura...". Aqui D. Laura hesitou e prosseguiu como quem se aventura a escalar o Sidnath:

"De resto a avó é uma pessoa de outros tempos, não gosta de ouvir certas coisas e reprova-as embora pareça animar as pessoas a falar nelas..."

"Mas isso não era só noutros tempos que se fazia, há muita gente que usa agora esse processo para tirar cagalhões...."

"Vai, vai com esse palavreado para ao pé da avó! Ouve ao menos. Por exemplo, a tua avó não gosta de gente alcoólica, mas quando quer entusiasmar as pessoas a falar, oferece-lhes da sua garrafaria, que, apesar de tudo, está bem provida, e, se elas mostram apreciar os licores, insiste em que bebam mais, e fica a ouvi-las, mas no seu íntimo reprova-as, percebes."

"Ah! É só isso, tá descansada, mãe!" Aqui, a Fatiminha lançou mão ao crayon e brincou com as suas sobrancelhas almejando o dia em que poria o lápis de verdade no seu bonito rosto de pele de cetim.

"Tem juízo", volveu a mãe, agora mais tranquila. "Se a avozinha te oferecer licores, já sabes que é para te soltar a língua e depois censura-me porque te eduquei mal..."

"Ora e depois?"

"Depois vem para ao pé do teu pai e faz-lhe queixas, portanto o melhor é evitares isso; quando ela te oferecer licores pede-Ihe que te dê Coca-Cola!"

Fátima riu-se muito diante daquela ideia de Coca-Cola e, ajeitando a bandolete pela décima vez, desapareceu como uma bólide para ir visitar uma pessoa que já era de idade avançada, que tinha uma bela garrafaria, que gostava de tagarelar e que era sua avó.

É noite; depois do jantar, diante do pai e irmãos, D. Laura perguntou à Fátima: "Então, a avó estava bem?" 
"Estava, guê, estava..."

"Disseste que eu fui ao Mandal?"

"Disse, guê, disse..."

A mãe, algo alarmada, encarou com atenção a sua morena vergôntea e inquiriu já de pé para atrás:

"Houve alguma novidade? Não beberam Coca-Cola?"

"Não, guê, não! A avó não quis, disse que dos fracos não reza a história!"

O pai da Fatiminha deixou cair o Times, pasmado, enquanto a sua cara metade avançava precipitada:

"Deixa aquele guê e conta lá, a avó não te convidou a provar dos licores da garrafaria, pois não?"

"Não! Não bebemos licor."

"Ainda bem...", disse aliviada D. Laura.

"Tomámos whisky puro e genuíno, as duas."

"Whisky?! Alfredo estás a ouvir a tua filha?"

"Não te preocupes, mãe, fiquei fixe como uma rocha e quem falou foi a avó. Calcula que até me contou que tu, levada por teu racial pedantismo, não deixavas que ela me embalasse em concani quando eu era bebé e, sempre que ela começasse a ensinar-me o tão lindo été été mohrá, tu vinhas a correr tirar-me do colinho d'avó e começavas desafinadamente querendo imitar portuguesinhas: - Papãozinho, vai-te embora... E eu punha-me a chorar porque não percebia o canto."

"Na verdade, ninguém pode enganar a avó!" - rematou Fatiminha, dando por findo o serão, enfiada num florido babydoll ante o ar miserável dos seus progenitores.

*No acima aludido não há referências a ninguém. Personagens e situações são produto de mera imaginação. 